\title{
Current situation and problems of natural gas distributed generation investment in China
}

\author{
Jun Dong ${ }^{1,}$ and Hongxin Cai ${ }^{1, b}$ \\ ${ }^{1}$ School of Economics and Management, North China Electric Power University, Beijing 102206, \\ China; \\ a327633089@qq.com, bcaihongxin2@126.com
}

Keywords: distributed generation, natural gas, investment, policy.

\begin{abstract}
Distributed power is not only as a backup power supply for power shortage, but also can meet the power demand of regional or urban power grid which not covered by centralized power generation, China has been developing these projects yet. This paper, mainly discussesinvestment status of natural gas distributed generation from development statuses, investment advantages and barriers. And for investment barriers, put forward investment proposals, to better promote China's natural gas distributed generation development.
\end{abstract}

\section{Introduction}

Energy can provide energy for human beings, as material basis for human survival and social development. Developing distributed generation (DG), is conducive to full use clean and renewable energy throughout the country, provide "green power", achieve energy conservation and emission reduction targets, and take the sustainable energy development path. DG investment should consider the factors of power demand and fuel price, such as diesel and gas gensets [1-3]. In August 2015, several utilities in California filed their own DG development plans to the Public Utilities Commission respectively, at the same time, enacted economic measures to encourage the development of DG [4].India supplied a large number of subsidies to encourage distributed energy generation including renewable energy [5]. Germany framed "the medium voltage distribution network grid technical standards "(1-60 kV), "the low voltage distribution network grid technical standards" (1 kV and below), in order to achieve distributed power connected to grid rapidly and ensure the safe and stable operation of power grids [6,7].Denmark is the highest energy use efficiency country in the world, and the introduction of Electricity Supply Bill, proposed power grid companies must purchase electricity of new energy power generation enterprises preferentially, and consumers also have the obligation to use new energy power generation capacity [8-10]. Japan's cogeneration development is benefit from the country's implementation of high depreciation and initial low tax loan policy, and the Development Bank of Japan for cogeneration project provides low interest loans [11,12]. The paper, introduced investment status of China's natural gas distributed generation, and distributed photovoltaic power generation from development status, investmentadvantages, investment barriers, and puts forward some investment suggestions according to the current barriers, in order to promote the development of distributed generation in China.

\section{Natural gas distributed generation}

\subsection{Development status}

With China's natural gas supply increasingly, the pace of the smart grid construction accelerating, the development of specialized energy service company rapidly, the main equipment of domestic natural gas distributed energy research independently, China has certain conditions for quickly developing natural gas distributed energy. The country also promulgated a series of main encouraging policies (as seen Table 1). 
Table 1 China related policies about natural gas distributed generation

\begin{tabular}{|c|c|c|}
\hline Time & Policy & Content \\
\hline $\begin{array}{l}\text { Next five to ten } \\
\text { years Specific Targets. }\end{array}$ & \multicolumn{2}{|c|}{$\begin{array}{l}\text { By 2020, China will promote the use of distributed energy system on the cities at } \\
\text { national scale, with installed capacity reaching } 50 \text { million kilowatts, and realize } \\
\text { distributed energy equipment industrialization initially. }\end{array}$} \\
\hline 2014.12 & $\begin{array}{l}\quad \text { Notice on the National } \\
\text { Development and Reform } \\
\text { Commission regulating the } \\
\text { electricity price management of } \\
\text { natural gas power generation }\end{array}$ & $\begin{array}{l}\text { When large changes in natural gas prices, } \\
\text { natural gas feed-in tariffshould be adjusted } \\
\text { timely, but the highest price shall not exceed the } \\
\text { local coal-fired power benchmark pricing or } \\
\text { average purchase price of } 0.35 \text { Yuan per kilowatt } \\
\text { hour of local power network enterprises. }\end{array}$ \\
\hline 2014.10 & $\begin{array}{l}\text { Notice on Issuing the } \\
\text { detailed implementation rules } \\
\text { for natural gas distributed } \\
\text { energy demonstration projects }\end{array}$ & $\begin{array}{l}\text { Optimize and simplify the reviewprogram, } \\
\text { speed up review progress, grid-tied declaration, } \\
\text { audit and approval process that should not more } \\
\text { than } 60 \text { working days in principle. }\end{array}$ \\
\hline 2013.11 & $\begin{array}{l}\text { Notice on the China State } \\
\text { Grid Corp issuing related ideas } \\
\text { and norms of distributed power } \\
\text { grid (Revised Edition) }\end{array}$ & $\begin{array}{l}\text { Whether generation capacity by distributed } \\
\text { power be all occupied or surplus electricity } \\
\text { access to grid selected by users themselves, the } \\
\text { lacking electricity provided by power grid. }\end{array}$ \\
\hline 2013.7 & $\begin{array}{c}\text { Distributed Generation } \\
\text { Management Interim Measures }\end{array}$ & $\begin{array}{l}\text { Power grid enterprise is responsible for } \\
\text { distributed power external network facilities and } \\
\text { investment in the partial construction of public } \\
\text { power grids caused by access, and provides } \\
\text { convenient, timely and efficient access services. }\end{array}$ \\
\hline 2012.6 & $\begin{array}{l}\text { Notice on the releasing the } \\
\text { first national distributed natural } \\
\text { gas energy demonstration } \\
\text { project }\end{array}$ & $\begin{array}{l}\text { The National Development and Reform } \\
\text { Commission, Ministry of Finance, Ministry of } \\
\text { Construction and the State Energy Bureau jointly } \\
\text { issued the notice, as Huadian Taizhou four items } \\
\text { for national demonstration projects, which means } \\
\text { the prelude of national natural gas distributed } \\
\text { energy demonstration projects for large-scale } \\
\text { construction has been opened. }\end{array}$ \\
\hline 2011.10 & $\begin{array}{l}\text { Guidance on developing } \\
\text { natural gas distributed energy }\end{array}$ & $\begin{array}{l}\text { During the "Twelfth Five Year Plan" period, } \\
\text { China will construct about } 1000 \text { natural gas } \\
\text { distributed energy projects, and intend to } \\
\text { construct about } 10 \text { distributed energy } \\
\text { demonstration areas withvarious typical } \\
\text { characteristics. }\end{array}$ \\
\hline
\end{tabular}

At present, the five power generation groups and grid companies are actively into the distributed natural gas energy. The Southern Power Grid Corp in Guangdong Foshan gas distributed energy station has been put into production, with energy utilization rate more than 75\%. Huaneng Group in Huizhou, Guangdong, Guodian Group in Guangdong, Shenzhen, Zhoushan Zhejiang, China Power Investment Corp in Shanghai, Zhuhai Guangdong, Datang Group in Guangyuan, Sichuan and other places, they all positively promote the construction of distributed natural gas energy projects. Industry predicts, if natural gas distributed energy installed capacity reach to 50 million kilowatts in 2020, China's total facility market capacity will exceed 200 billion yuan, including all types of combustion engine about 150 billion yuan, waste heat boiler about 25 billion yuan, which will be a huge investment opportunity for natural gas distributed generation.

\subsection{Investment advantages.}

\section{1) Project advantages}

Natural gas transmission is not affected by climate, and can save locally. City or region has certain scale of distributed natural gas energy supply system, with increasing independent power generation ability, which is securer than relying on the power grid supply system solely.Distributed natural gas energy projects can be interruptible, adjustable power system, for natural gas and electric power with double "peak load shifting" effect. Effectively alleviate the natural gas peak valley difference between winter and summer, improve the utilization efficiency of summer gas 
facilities, and enhance the safety of gas supply system, what's more, decrease the peak installed capacity and investment in natural gas storage facilities, and lower operation cost of power network and natural gas pipeline network.

2) Economic benefit

Natural gas distributed energy system can realize energy cascade utilization, make full use of power generation waste heat, local heating, electricity, reduce loss of electricity and heat in long distance transportation, energy comprehensive utilization rate is more than doubled in large coal-fired electricity generating units; while saving investment cost in power grid, heat pipe network transmission, bring about huge economic benefits.In addition to own economic benefits, it also has a corresponding economic impact on environment. Adopt distributed system with clean energy, can greatly reduce pollutant emissions like carbon dioxide.

3) Policy support

- Planning ahead: government departments formulate natural gas distributed energy special planning, do coordination with urban gas, heating development planning;

- Standard accessories: government departments develop power grid-tied rules and bidding process, scientific and rational environmental regulations and supporting application for fire conditions;

- Investment subsidies: give appropriate investment subsidies to distributed energy projects, such as Shanghai, Changsha and Beijing city;

- Preferential policies: government departments to give privilegein electricity prices, gas prices, heating prices.

\section{Investment barriers and suggestions}

Although natural gas distributed generation investment has certain advantages, there are barriers. Table 2 summarizes the barriers of natural gas distributed generation, and put forward investment development suggestions.

Table 2 Investment barriers and suggestions of natural gas distributed generation

\begin{tabular}{l|l}
\hline \multicolumn{1}{c|}{ Investment barriers } & \multicolumn{1}{c}{ Suggestions } \\
\hline $\begin{array}{l}\text { Economy matter:Lacking gas turbine technologyand } \\
\text { higher natural gas price influences economy of } \\
\text { natural gas distributed generation development. More } \\
\text { recently, non-residents with gas prices down 0.7 }\end{array}$ & $\begin{array}{l}\text { Strengthen } \\
\text { development, reduce equipment project cost: } \\
\text { On the one hand, should strengthen the research } \\
\text { and development of gas turbine key technologies. }\end{array}$ \\
$\begin{array}{l}\text { yuan/square, price ratio between industrial gas and } \\
\text { coal have improved, but still at a disadvantage. After } \\
\text { adjustment, gas-fired boiler fuel cost higher than } \\
\text { coal-fired boilers (anthracite) 10\%, higher than } \\
\text { coal-fired boilers (coal) 64\%. }\end{array}$ & $\begin{array}{l}\text { cost as soon as possible; on the other hand, } \\
\text { develop energy multiple use to control costs } \\
\text { reasonably. }\end{array}$ \\
\hline $\begin{array}{l}\text { Grid connection matter: Because of the instability, } \\
\text { profit and management factors, grid-tied issue has } \\
\text { become an important problem in the development of } \\
\text { distributed energy from the beginning, the same as } \\
\text { distributed generation gas. The issue affect planning } \\
\text { and design, power quality, scheduling operation of }\end{array}$ & $\begin{array}{l}\text { Change grid connection form: According to the } \\
\text { characteristics of the natural gas distributed } \\
\text { power system. }\end{array}$ \\
$\begin{array}{l}\text { specific users, to realize the surplus of distributed } \\
\text { energy access to the electricity grid, get electricity } \\
\text { from grid lacking electricity,and avoid shocking } \\
\text { on the public power grid safe and stable operation } \\
\text { possibily. }\end{array}$ \\
\hline $\begin{array}{l}\text { Profit matter: Target users of natural gas distributed } \\
\text { generationare bank, hospital, office center premium }\end{array}$ & $\begin{array}{l}\text { Perfect gas price mechanism: Perfect power grid } \\
\text { auxiliary service compensation mechanism such }\end{array}$ \\
$\begin{array}{l}\text { users, will damage the interests of power grid to a } \\
\text { certain extent. }\end{array}$ & $\begin{array}{l}\text { as peak load and frequency regulation, improve } \\
\text { the compensation cost and cover gas power plants } \\
\text { increased fuel costs and high maintenance cost for } \\
\text { taking frequent peaking.Implement and improve } \\
\text { national policies, clear price anddistribute } \\
\text { earningsreasonably. }\end{array}$ \\
\hline
\end{tabular}




\section{Summary}

China current distributed generation, has strong energy resources base, rapid technology development, huge potential market, rising policy support degree continually these advantages. After the concept of distributed generation was put forward in the country, under the leadership of national policy, the distributed generation has been developed. But in the face of lacking core technology, grid connection, unsound policy system and other barriers, invest distributed generation coexist with opportunities and risks. This paper, through analyzing natural gas distributed generation investment status, know about existing technology, grid connection, profit barriers, then put forward establishing policies and incentive mechanism, normalizing distributed energy access grid, researching own technology these suggestions, in order to promote the investment of natural gas distributed generation in China.

\section{References}

[1]. Siddiqui A S, Marnay C. Distributed generation investment by a microgrid under uncertainty. Energy.Vol.33(2008)No.12,p.1729-1737.

[2]. RajiAtia, Noboru Yamada. Distributed Renewable Generation and Storage System Sizing Based on Smart Dispatch of Microgrids. Energies.Vol. 9(2016)No. 3, p. 176.

[3]. Ruppert M, Hayn M, Bertsch V, et al. Impact of residential electricity tariffs with variable energy prices on low voltage grids with photovoltaic generation. International Journal of Electrical Power \& Energy Systems.Vol. 79(2016) p. 161-171.

[4]. Amor M B, Pineau P O, Gaudreault C, et al.Assessing the economic value of renewable distributed generation in the Northeastern American market. Renewable \& Sustainable Energy Reviews. Vol. 16(2012)No.8, p. 5687-5695.

[5]. Sharma N K, Sood Y R. Reduction in subsidy for solar power as distributed electricity generation in Indian future competitive power market. Journal of Renewable \& Sustainable Energy.Vol. 4(2012)No.5, p. 358-371.

[6]. Roy N K, Pota H R. Current Status and Issues of Concern for the Integration of Distributed Generation Into Electricity Networks. IEEE Systems Journal.Vol. 9(2014) p. 1-12.

[7]. Jun Dong, Tian-tian Feng, Hong-xing Sun, Hong-xin Cai. Clean distributed generation in China: Policy options and international experience. Renewable and Sustainable Energy Reviews.Vol. 57(2016) p. 753-764.

[8]. Lehtonen M, Nye S. History of electricity network control and distributed generation in the UK and Western Denmark. Energy Policy.Vol. 37(2009)No. 6, p. 2338-2345.

[9]. Sovacool B K. Energy policymaking in Denmark: Implications for global energy security and sustainability. Energy Policy.Vol.61(2013)No. 10, p. 829-839.

[10]. Anaya K L, Pollitt M G. Integrating distributed generation: Regulation and trends in three leading countries. Energy Policy.Vol. 85(2015) p. 475-486.

[11]. Nasu H, Faunce T A. Nanotechnology in Japan: A route to energy security after Fukushima?. Bulletin of the Atomic Scientists.Vol. 69(2013) No. 5, p. 68-74.

[12]. Arai J, Iba K, Funabashi T, et al. Power electronics and its applications to renewable energy in Japan. IEEE Circuits \& Systems Magazine. Vol. 8(2008) No. 3, p. 52-66. 